\title{
MUTU BRIKET ARANG KULIT BUAH KAKAO DENGAN MENGGUNAKAN KANJI SEBAGAI PEREKAT
}

\author{
Quality of Charcoal Briquette from Cocoa Pod Shell using Starch as Adhesive
}

M. Natsir Usman

\begin{abstract}
The development of an alternative energy is now becoming important due to the decrease of natural energy source, The current research was conducted to observe the quality of making charcoal briquette from cocoa pod shell with the particle size of 30 mesh, 50 mesh, 70 mesh and $7 \%$ starch as adhesive. The result showed that charcoal particle size of 70 mesh gave the best charcoal briquette quality having characteristics: moisture $10.67 \%$, density of $1.15 \mathrm{~g} / \mathrm{cm}^{3}, 18.98 \%$ ash content, $49.93 \%$ fixed carbon, $24.99 \%$ volatile matter and the calorific value of $4372.54 \mathrm{cal} / \mathrm{g}$.

Charcoal briquette from cocoa pod shell was utilized as alternative energy.
\end{abstract}

Key words: Cocoa pod shell, charcoal briquette, starch as adhesive.

\section{PENDAHULUAN}

Semakin berkurangnya sumber minyak bumi yang merupakan sumber energi utama saat ini, telah menyebabkan manusia mencari sumber energi alternatif, keadaan ini mendorong upaya mengembangkan sumber energi selain minyak dan gas bumi. Sumber energi alternatif yang dapat diperbaharui (renewable) yang cukup potensial adalah limbah hasil perkebunan yang sampai saat ini belum termanfaatkan secara optimal. Pemanfaatan limbah perkebunan sebagai salah satu sumber energi alternatif yang diharapkan juga dapat menggeser atau mensubstitusi pemakaian kayu bakar untuk rumah tangga. Kayu sebagai bahan bakar dinegara sedang berkembang mencapai 75 sampai 90 persen dari konsumsi secara keseluruhan (Agussalim, 1995). Pembuatan briket arang dari limbah hasil pertanian khususnya limbah hasil perkebunan merupakan salah satu cara untuk menggali sumber energi yang potensial, mengingat saat ini bahan dari kehutanan kurang begitu menarik dalam pemanfaatannya, sebab dapat menimbulkan asap dan nilai kalorinya lebih rendah dari pada briket arang. Salah satu limbah hasil perkebunan yang cukup potensial di Indonesia khususnya di Sulawesi Selatan adalah buah kakao. Pada tahun 1999 luas areal perkebunan kakao di Sulawesi Selatan sebesar 228.312 ha dengan jumlah produksi sebesar 208.788 ton dan pada tahun 2005 luas areal perkebunan 222.566,82 ha dengan jumlah produksi sebesar 178.424,61 ton (Sulawesi Selatan dalam Angka Tahun 1999 dan Tahun 2005). Penggunaan briket arang dapat juga dimanfaatkan untuk pengeringan kakao, yang selama ini banyak menggunakan pengeringan energi matahari, briket arang yang dihasilkan dalam penelitian ini akan dibandingkan dengan kualitas briket arang buatan Jepang dan briket arang impor. Tujuan penelitian ini adalah untuk mengetahui ukuran partikel dengan perekat kanji terhadap mutu briket arang dari kulit buah kakao.

\section{BAHAN DAN METODE}

\section{Bahan dan Peralatan}

Bahan baku yang digunakan dalam penelitian ini adalah kulit buah kakao, perekat kanji, dan bahan lainnya, sedang peralatan yang digunakan adalah klin (tungku karbonisasi), tungku pembakaran, hammer mill, shaking screen (pengayak), oven listrik, bomb kalorimeter, eksikator, alat pembriket hidraulik, alat pengukur tekanan kempa, gelas ukur dan peralatan lainlainnya.

\section{Metode Penelitian}

Penyiapan bahan baku

Bahan baku kulit buah kakao yang masih basah dipotong-potong kecil, kemudian 
dikeringkan sampai kadar air kering udara selama lima hari.

\section{Karbonisasi}

Kulit buah kakao kering dimasukkan dalam tungku selama 4 sampai 5 jam, kemudian dilakukan pendinginan selama 12 jam. Hasil karbonisasi kemudian dihaluskan dengan hammer mill, lalu diayak dengan ukuran 30,50 , dan 70 mesh.

\section{Pembuatan adonan}

Serbuk dengan kehalusan 30, 50 dan 70 mesh dicampur dengan perekat kanji yang telah disiapkan dengan konsentrasi $7 \%$ dari berat arang. Campur sampai homogen, masukkan dalam cetakan, kempa dengan alat pembriket hidraulik pada tekanan 70 ton. Briket arang hasil pencetakan dikeringkan dalam oven pengering pada suhu 90 ${ }^{\circ} \mathrm{C}$ selama 24 jam. Briket dikelurkan dari oven dan didinginkan dalam eksikator. Briket arang siap untuk diuji atau dianalisis.

\section{Pengujian atau analisis}

Analisis mutu briket arang kulit buah kakao meliputi kadar air, kadar abu, kadar zat mudah terbang, kerapatan, kadar karbon terikat dan nilai kalori.

\section{HASIL DAN PEMBAHASAN}

Rata-rata hasil pengujian atau analisis mutu briket kulit buah kakao disajikan pada Tabel 1. Mengacu pada Tabel 1 dapat dikemukakan uraian beberapa parameter analisis sebagai berikut:

\section{Kadar Air}

Kadar air briket arang kulit buah kakao bervariasi antara 7,99 sampai 10,67 \%. Kadar air terendah sebesar 7,99 \% diperoleh dari perlakuan ukuran partikel arang 30 mesh (a1) dan tertinggi sebesar $10,67 \%$ dari ukuran partikel 70 mesh (a3). Bila dibanding dengan kadar air standar briket arang buatan Jepang dan briket arang impor (6-8 \%), maka briket arang kulit buah kakao dalam penelitian ini tidak memenuhi syarat mutu kecuali ukuran partikel 30 mesh, hal ini mungkin disebabkan karena belum sempurnanya pengeringan dengan waktu pengeringan dalam oven masih perlu diperpanjang, selain itu ukuran partikel juga dapat mempengaruhi kadar air, partikel yang kasar lebih sedikit menyerap air dibanding dengan partikel yang lebih halus.

\section{Kadar Abu}

Kadar abu briket kulit buah kakao bervariasi antara 18,03 \% sampai 18,98\%. Kadar abu terendah sebesar 18,03\% diperoleh dari perlakuan ukuran partikel 30 mesh (a1) dan tertinggi sebesar 18,98 \% (a3). Kadar abu antara lain dipengaruhi oleh kualitas bahan baku yang digunakan. Untuk kulit buah kakao merupakan bahan baku berkualitas rendah dan diperkirakan banyak mengandung zat ekstraktif yang tinggi, sehingga kandungan mineral-mineral dalam abu cukup tinggi seperti kalsium dan lainnya, sehingga pada proses pembakaran briket tersebut banyak meninggalkan abu sebagai sisa pembakaran. Kadar abu yang tinggi dapat mempengaruhi nilai kalori suatu briket arang. Kadar abu briket kulit buah kakao bila dibanding dengan kadar abu briket arang buatan Jepang dan briket arang buatan impor (3-6 \%), maka semua ukuran partikel 30 mesh, 50 mesh dan 70 mesh (al, a2 , a3) tidak memenuhi standar mutu. Kadar abu tinggi menyebabkan kadar karbon terikat menjadi rendah atau sebaliknya (Hartoyo dan Nurhayati, 1976).

Tablel 1.Quality average of observed charcoal briquette from cocoa pod shell

\begin{tabular}{lccc}
\hline \multirow{2}{*}{ Parameter uji } & \multicolumn{3}{c}{ Perlakuan } \\
\cline { 2 - 4 } & a1 & Ukuran partikel arang $(\mathrm{A})$ \\
\cline { 2 - 4 } & 7.99 & 10.08 & a3 \\
\hline - kadar air (\%) & 18.03 & 18.48 & 10.67 \\
- kadar abu (\%) & 24.05 & 24.32 & 18.98 \\
- Zat mudah terbang (\%) & 45.36 & 47.11 & 24.99 \\
- Karbon terikat (\%) & 0.96 & 0.98 & 49.93 \\
- Kerapatan $\left(\mathrm{g} / \mathrm{cm}^{3}\right)$ & 4163.11 & 4281.61 & 1.15 \\
-Nilai Kalori (kal/g) & & & 4372.54 \\
\hline
\end{tabular}

Keterangan: *) Rata-rata tiga kali ulangan 


\section{Kerapatan}

Kerapatan briket kulit buah kakao bervariasi antara $0.96-1,15 \mathrm{~g} / \mathrm{cm}^{3}$. Kerapatan terendah sebesar $0,96 \mathrm{~g} / \mathrm{cm}^{3}$ diperoleh dari perlakuan briket arang ukuran partikel 30 mesh (a1) dan tertinggi sebesar $1,15 \mathrm{~g} / \mathrm{cm}^{3}$ dari ukuran partikel 70 mesh (a3). Tinggi rendahnya kerapatan dari briket arang kulit buah kakao sangat dipengaruhi oleh ukuran partikel yang digunakan. Menurut Sudrajat (1983), kerapatan briket arang kulit buah kakao dipengaruhi oleh kualitas bahan yang digunakan. Untuk kayu dengan kerapatan tinggi cenderung menghasilkan arang atau briket arang yang mutunya tinggi pula. Lebih lanjut dikatakan bahwa ukuran partikel arang yang digunakan juga mempengaruhi kerapatan, makin kecil ukuran partikel arang, kerapatan briket arang yang dihasilkan semakin tinggi, ini terlihat pada ukuran partikel arang 70 mesh (a3) kerapatannya lebih tinggi dibanding dengan partikel arang lainnya (30 mesh dan 50 mesh ). Hal ini mungkin disebabkan karena makin kecilnya pori-pori antara partikel arang sehingga semakin besar berat persatuan volumenya. Persentase perekat yang digunakan dalam penelitian ini sebesar $7 \%$ mampu untuk memperbesar kerapatan karena dengan kadar yang demikian masih dapat diserap oleh partikel arang dan pori-pori antara partikel sehingga semua perekat dapat diserap oleh partikel-partikel tersebut sehingga tidak ada perekat yang terbuang pada saat pencetakan atau pengempaan. Selain itu kerapatan dipengaruhi oleh homogenitas campuran perekat dengan arang, dengan pengadukan yang semakin merata, maka briket arang yang dihasilkan akan semakin kuat, hal ini menyebabkan partikel arang cukup merata. Kerapatan suatu briket arang sangat berguna dalam transportasi dan pengepakan, agar briket tidak mudah hancur dan pengepakan lebih muda. Bila dibanding dengan standar mutu briket arang buatan Jepang dan briket buatan impor (1-2 $\left.\mathrm{g} / \mathrm{cm}^{3}\right)$, maka briket arang kulit buah kakao dari semua perlakuan ukuran partikel dari 30, 50 dan 70 mesh (a1, a2 dan a3) hanya ukuran partikel 70 mesh yang memenuhi standar mutu, sementara briket arang impor tidak mensyaratkan parameter kerapatan.

\section{Zat Mudah Terbang}

Zat mudah terbang briket kulit buah kakao bervariasi antara 24,05-24,99 \%. Zat mudah terbang terendah sebesar $24,05 \%$ diperoleh dari arang dengan ukuran partikel 30 mesh (a1) dan tertinggi sebesar $24,99 \%$ pada ukuran partikel arang 70 mesh (a3). Tinggi rendahnya zat mudah terbang banyak dipengaruhi oleh komponen kimia dari arang seperti adanya zat ekstraktif dari bahan baku arang. Bila dibanding dengan standar mutu arang buatan Jepang dan briket arang impor (15-30\%), maka briket arang kulit buah kakao baik ukuran partikel 30 mesh, 50 mesh dan 70 mesh masih memenuhi standar mutu briket arang buatan Jepang maupun briket impor.

\section{Kadar Karbon Terikat}

Kadar karbon terikat briket arang kulit buah kakao bervariasi antara 45,35-49,93 \%. Kadar karbon terikat terendah sebesar 45,36 \% diperoleh dari briket arang dengan ukuran partikel 30 mesh (a1) dan tertinggi sebesar 49,93\% pada ukuran partikel 70 mesh (a3). Nilai kandungan karbon terikat dipengaruhi oleh nilai zat mudah terbang dan kadar abu. Menurut Nurhayati (1976), bahwa semakin tinggi zat mudah terbang, maka semakin rendah nilai karbon terikat, begitu pula sebaliknya. Demikian juga bila kadar abu tinggi maka semakin rendah kadar karbon terikatnya. Bila dibanding dengan standar briket arang buatan Jepang dan briket arang buatan impor $(60-80 \%)$ maka briket arang kulit buah kakao dari semua ukuran partikel dari 30 mesh, 50 mesh dan 70 mesh (a1, a2 ,a3) semuanya tidak memenuhi standar mutu.

\section{Nilai Kalori}

Nilai kalori briket arang kulit buah kakao bervariasi antara 4163,11-4372,54 kal/g. Nilai kalori terendah sebesar $4163,11 \mathrm{kal} / \mathrm{g}$ diperoleh dari ukuran partikel 30 mesh (a1) dan tertinggi sebesar 4372,54 kal/g pada ukuran partikel 70 mesh (a3). Nilai kalori briket arang antara lain dipengaruhi oleh ukuran partikel arang, kerapatan dan bahan baku arang. Makin kecil ukuran partikel maka nilai kalorinya makin tinggi, demikian juga semakin kecil ukuran partikel semakin tinggi pula kerapatannya, hal ini sejalan dengan Sudrajat (1983), mengatakan bahwa kayu dengan berat jenis tinggi, cenderung menghasilkan briket dengan nilai kalori tinggi. Nilai kalori briket arang sangat penting karena ada kaitannya dengan efisiensi atau penghematan suatu bahan bakar. Apabila nilai 
kalor rendah berarti jumlah bahan bakar yang digunakan dan dibutuhkan untuk pembakaran atau pemanasan akan lebih banyak, tetapi bila nilai kalornya tinggi berarti jumlah bahan bakar yang digunakan untuk pembakaran akan lebih sedikit, nilai kalori briket arang merupakan parameter penting dalam menentukan kualitas briket arang, layak atau tidak digunakan sebagai bahan bakar. Semakin tinggi nilai kalori suatu briket arang makin tinggi pula kualitasnya dan harga jualnya pun akan tinggi. Bila dibanding dengan standar briket arang buatan Jepang dan briket arang buatan impor (6000-7000 kal/g), maka briket arang kulit buah kakao dari semua perlakuan partikel 30 mesh, 50 mesh dan 70 mesh (a1, a2, a3) semuanya tidak memenuhi standar mutu, yang berarti briket kulit buah kakao termasuk kualitas rendah dan hanya sebanding dengan nilai kalor kayu bakar.

\section{KESIMPULAN}

Dari hasil penelitian ini dapat diambil beberapa kesimpulan sebagai berikut:

1. Kulit buah kakao termasuk bahan baku arang yang berkualitas rendah dengan mutu briket arang yang tidak memenuhi standar mutu.

2. Briket arang kulit buah kakao tidak memenuhi standar mutu briket arang buatan Jepang maupun briket arang buatan impor kecuali parameter kerapatan dengan ukuran partikel 70 mesh (a3) dan kadar air ukuran partikel 30 mesh (a1).

3. Briket arang kulit buah kakao dengan ukuran partikel 70 mesh (a3) merupakan perlakuan terbaik dalam penelitian ini.

4. Briket arang kulit buah kakao walaupun mutunya rendah masih dapat digunakan sebagai bahan bakar alternatif seperti halnya pada kayu bakar.

\section{DAFTAR PUSTAKA}

Agussalim. 1995. Pengaruh Ukuran Butir Arang dan Persentase Perekat dalam Pembuatan Briket Arang Kombinasi Limbah Tandan Kosong Kelapa Sawit dengan Arang Tempurung Kelapa Sawit. Laporan Hasil Penelitian Teknologi Pertanian, Universitas Hasanuddin, Ujung Pandang.

Anonim. 1993. Sulawesi Selatan dalam Angka. Badan Pusat Statistik (BPS), Propinsi Sulawesi Selatan, Ujung Pandang. 2006. Sulawesi Selatan dalam Angka. Badan Pusat Statistik (BPS). Propinsi Sulawesi Selatan, Ujung Pandang.

Hartoyo dan Nurhayati. 1976. Pengaruh Berat Jenis Kayu Daun Lebar terhadap Sifat Arang. Laporan No.72, LPHH, Bogor.

Nurhayati. 1976. Nilai Kalori Beberapa Jenis Kayu di Indonesia dan Hubungannya dengan Berat Jenis. Laporan Pusat Penelitian dan Pengembangan Hasil Hutan, No.169, Bogor.

Sudrajat. 1982. Produksi Arang dan Briket Arang serta Prospek Pengusahaannya dalam Pembuatan Briket Arang dari Kayu Manis (Cinnamomu burmanii Nees ex BL) dan kayu sukun (Artocarpus Altilis Parkinson). Jurnal Penelitian Hasil Hutan, 12(6)

1983. Pengaruh Bahan Baku, Jenis Perekat dan Tekanan Pengempaan terhadap Kualitas Briket Arang. Laporan Pusat Penelitian Hasil Hutan No.l65, Bogor.

Diterima : 25 Mei 2007

M. Natsir Usman

Balai Besar Industri Hasil Perkebunan

Jl. Racing Center No.28, Makassar Baharuddin 